\title{
Three Decades of U.S. Gulf of Mexico White Shrimp, Litopenaeus setiferus, Commercial Catch Statistics
}

\author{
RICK A. HART and JAMES M. NANCE
}

\section{Introduction}

The primary U.S. white shrimp, Litopenaeus setiferus, fishing grounds are located in the northern Gulf of Mexico (GOM), consisting of inshore and near-shore habitats favorable for L. setiferus survival and conducive to commercial fishing operations (Fig. 1) (Kutkuhn, 1962; Nance et al., 2010). This fishery has been studied extensively as early as the 1930's (Burkenroad, 1934, 1939) as it was the first fishery to fully exploit a Gulf of Mexico shrimp stock (Linder and Anderson, 1956).

The white shrimp fishery was primarily prosecuted in the shallower water of the bays and inshore estuaries using cast nets and haul seines (Klima et al., 1982). When the otter trawl was

The authors are with the Fisheries Management Branch, Galveston Laboratory, Southeast Fisheries Science Center, National Marine Fisheries Service, NOAA, 4700 Avenue U, Galveston, TX 77551 (corresponding author is rick.hart@noaa. gov).

doi: dx.doi.org/10.7755/MFR.75.4.3

ABSTRACT - Gulf of Mexico, white shrimp, Litopenaeus setiferus, catch statistics have been collected by NOAA's National Marine Fisheries Service for over 50 years. Recent occurrences such as natural and manmade disasters have raised awareness for the need to publish these types of data. Here we report shrimp data collected from 1984 to 2011. These 28 years of catch history are the time series used in the most recent Gulf of Mexico white shrimp stock assessment. Fishing effort for this stock has fluctuated over the period reported, ranging from 54,675 to 162,952 days fished. Catch aver- introduced to the Gulf shrimp fishery in 1915, it allowed fishermen to fish the deeper offshore habitats (Klima et al., 1982). Due in part to the widespread use of this gear by the 1930's (Klima et al., 1982), catches of white shrimp increased causing management to become concerned with the heavy levels of exploitation.

The fishery was already heavily capitalized beginning in the 1950's and, in their review, Condrey and Fuller (1992) noted that there was an early concern for the potential for both growth and recruitment overfishing. However, after WWII this concern abated as the discovery of the commercial brown shrimp, Farfantepenaeus aztecus, fishing grounds, and subsequent buildup of this more offshore fishery, relieved some of the fishing pressure exhibited on white shrimp stocks (Condrey and Fuller, 1992).

More recently, management concerns have become focused primarily on decreasing the potential for recruitment overfishing, while growth overfishing seems to be of little concern to

aged 55.7 million pounds per year, increasing significantly over the times series. In addition, catch rates have been increasing in recent years, with CPUE levels ranging from $315 \mathrm{lb} /$ day fished in 2002, to $1,175 \mathrm{lb} /$ day fished in 2008. The high CPUE's we have measured is one indication that the stock was not in decline during this time period. Consequently, we believe the decline in effort levels is due purely to economic factors. Current stock assessments are now using these baseline data to provide managers with further insights into the Gulf L. setiferus stocks. managers (Nance et al., 2010, provided an overview of white shrimp management). Management attention has also been given to the identification and protection of essential fish habitat (EFH) for shrimp (Baker and Minello, 2010; Rozas and Minello, 2011).

Recent events affecting the white shrimp fishery, and nursery habitats in particular, have made it imperative that accurate documentation of catch histories for all of the GOM shrimp stocks be published (Hart et al., 2012). British Petroleum's Macondo exploration oil well catastrophe in 2010, Hurricanes Katrina and Rita (2005) and Ike (2008), sea level rise, and climate change all have the potential to impact essential white shrimp habitat and hence reduce shrimp production.

Here we have documented catch and effort statistics for the commercial $L$. setiferus fishery in the northern GOM. These catch statistics, in conjunction with state and Federal fishery independent surveys, are currently used as inputs in National Marine Fisheries Service (NMFS) stock assessment models estimating fishing mortality rates, spawning biomass, and annual recruitment numbers, with model outputs used as indices to gauge the status of the stock (Hart, 2012).

\section{Methods}

Records of the commercial harvest of L. setiferus have been collected for several decades, beginning in the 1950's (Kutkuhn, 1962). Commercial L. setiferus fishery statistics such as fishing effort, catch by size, and catch per unit effort (CPUE) are collected monthly throughout the GOM, using 


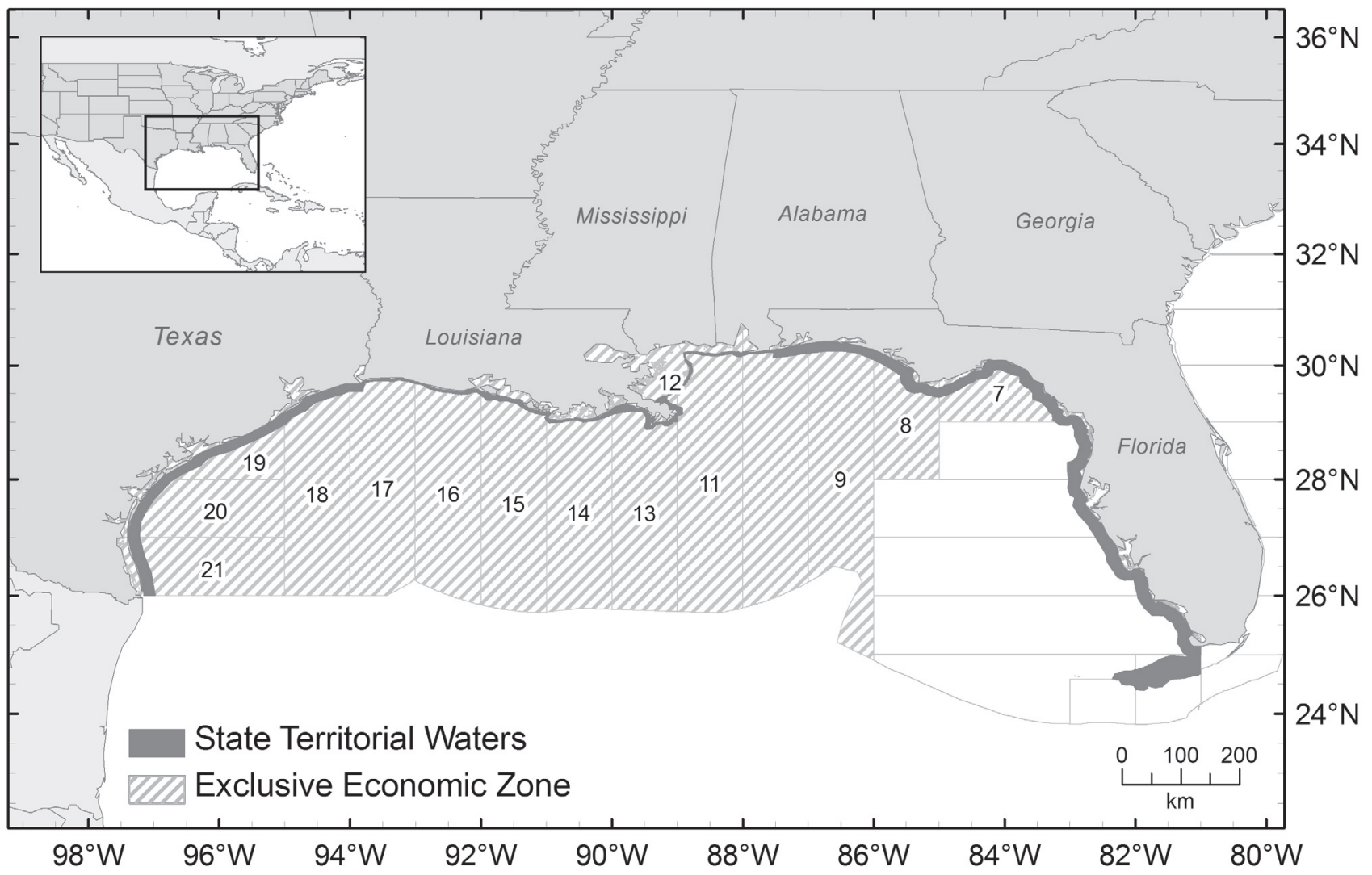

Figure 1.-U.S. Gulf of Mexico Litopenaeus setiferus fishing grounds, statistical zones 7-21.

standard collection methods (Nance et al., 2008).

NMFS port agents and state trip tickets record the daily operations and shrimp production of the commercial fisheries fleet operating within the boundaries of the U.S. GOM. To assist in the assignment of fishing locations, scientists have subdivided the U.S. Gulf of Mexico into 21 statistical subareas (Patella, 1975) (Fig. 1). These subdivisions are used by the port agents and state trip ticket system to assign the location of catches and fishing effort expended by the shrimp fleet on a trip by trip basis. The $L$. setiferus fishing grounds are located primarily within subareas 7-21 (Fig. 1).

Port agents randomly visit fishing ports throughout the Gulf of Mexico to interview fishing captains and/ or crews and record data pertaining to trawling activity and the number of days fished (fishing effort). These data include the location, depth, and days fished, by statistical subarea; the species specific pounds and sizes of shrimp landed (heads off weight, i.e., tails); and the commercial value of the catch for each individual trip that a vessel has completed (Nance et al., 1989).

To calculate effort (i.e., the amount of time in hours the trawls are actually in the water fishing), catch, and CPUE statistics, we used the methods outlined in Nance et al. (2008). Beginning with pilot studies in 1999, an electronic logbook program (ELB) was initiated to augment shrimp fishing effort measurements. Gallaway et al., (2003a, b) provides an in-depth description of this ELB data collection program and data collection procedures. Beginning in 2006 these ELB data are used to supplement the effort and location data collected by NMFS port agents and state trip tickets (Nance et al., 2008).

The commercial shrimp statistics are entered into an Oracle $^{1}$ relational database maintained and managed by fisheries staff under the direction of the NMFS Southeast Fisheries Science Center, Miami, Fla. We have summarized those 1984-2011 catch statistics which are of primary importance for the establishment of baseline information that are incorporated in the NMFS L. setiferus stock assessments (Hart, 2012). We also examine temporal relationships among years for effort, catch, and catch rates using simple correlation and regression methodologies (Zar, 1984).

${ }^{1}$ Mention of trade names or commercial firms does not imply endorsement by the National Marine Fisheries Service, NOAA. 


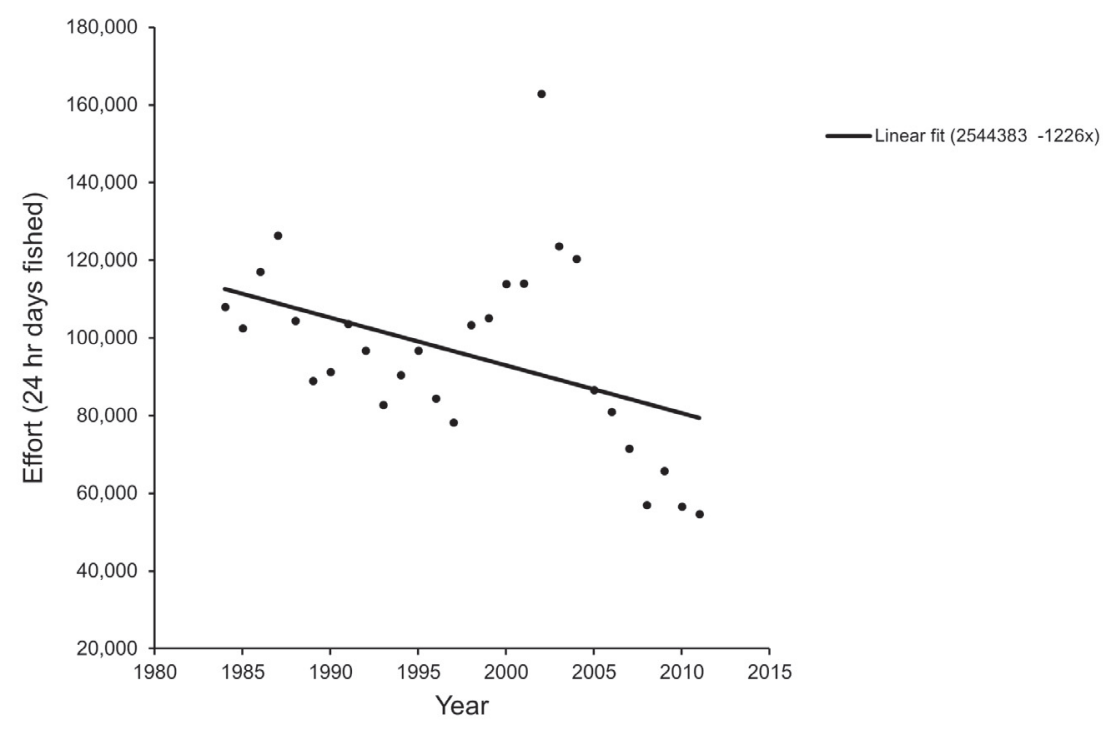

Figure 2.-Litopenaeus setiferus fishing effort vs. year, 1984-2011.

\section{Results}

\section{Fishing Effort}

Fishing effort, as measured in 24 $\mathrm{h}$ days fished (i.e., trawls in water) has shown fluctuations over the 28-yr time period presented in this analysis, ranging from 54,675 to 162,952 days fished (Fig. 2, Table 1). Effort values averaged 96,029 days fished, declining over the 28-yr time period, $(\mathrm{F}=5.53$, $\mathrm{df}=1,26, \mathrm{P}=0.03, \mathrm{R}^{2}=0.18$ ) (Fig. 2). Effort during the period of 1998-2004 was at record high levels with a record 162,952 days fished recorded in 2002. Effort levels are currently at the lowest levels on record with only 54,675 days fished in 2011.

\section{Annual Shrimp Catch}

Catch, as measured in shrimp tails, has been steadily increasing over the time series $(\mathrm{F}=8.56, \mathrm{df}=1,26, \mathrm{P}=0.007$, $\mathrm{R}^{2}=0.25$ ) (Fig. 3). From 1984 through 2011, L. setiferus catch averaged 55.7 \pm 12.5 million $\mathrm{lb}$ (SD) (Table 1). Record numbers of $L$. setiferus were caught in 2006 (86.2 million lb). In contrast, the lowest catch on record for this time series occurred in 1996 with only 35.9 million $\mathrm{lb}$ of $L$. setiferus tails harvested from statistical zones 7-21 (Fig. 3).
Table 1.-Gulf of Mexico, USA, Litopenaeus setiferus commercial catch statistics, 1984-2011.

\begin{tabular}{cccc}
\hline Year & $\begin{array}{c}\text { Catch } \\
\text { (lb of tails) }\end{array}$ & $\begin{array}{c}\text { CPUE } \\
\text { (lb/day fished) }\end{array}$ & $\begin{array}{c}\text { Effort } \\
\text { (days fished) }\end{array}$ \\
\hline 1984 & $56,030,981$ & 446 & 108,007 \\
1985 & $58,912,565$ & 523 & 102,532 \\
1986 & $70,737,609$ & 558 & 117,064 \\
1987 & $53,443,843$ & 417 & 126,427 \\
1988 & $45,167,720$ & 418 & 104,429 \\
1989 & $36,573,614$ & 397 & 88,939 \\
1990 & $44,246,398$ & 467 & 91,316 \\
1991 & $45,796,242$ & 549 & 103,642 \\
1992 & $47,965,715$ & 454 & 96,782 \\
1993 & $39,061,982$ & 458 & 82,746 \\
1994 & $45,966,758$ & 466 & 90,431 \\
1995 & $49,262,652$ & 503 & 96,801 \\
1996 & $35,872,529$ & 418 & 84,410 \\
1997 & $39,114,562$ & 491 & 78,261 \\
1998 & $54,871,213$ & 565 & 103,385 \\
1999 & $54,956,418$ & 490 & 105,200 \\
2000 & $70,216,291$ & 567 & 113,953 \\
2001 & $53,391,418$ & 421 & 114,103 \\
2002 & $53,348,737$ & 316 & 162,952 \\
2003 & $60,996,687$ & 524 & 123,715 \\
2004 & $72,873,648$ & 606 & 120,384 \\
2005 & $65,314,218$ & 772 & 86,662 \\
2006 & $86,216,341$ & 1,030 & 80,963 \\
2007 & $64,305,379$ & 873 & 71,612 \\
2008 & $63,728,659$ & 1,175 & 56,999 \\
2009 & $74,966,922$ & 1,130 & 65,787 \\
2010 & $59,520,631$ & 1,060 & 56,641 \\
2011 & $57,782,441$ & 1,115 & 54,675 \\
\hline & & & \\
\hline
\end{tabular}

\section{Catch Per Unit of Effort (CPUE)}

Catch per unit of effort is reported as pounds of shrimp caught during a $24 \mathrm{~h}$ fishing day (lb per nominal day fished). Catch per unit of effort averaged $614 \mathrm{lb} /$ day fished in statistical areas 7-21 (Table 1) during 1984-2011. Harvest rates over this time series ranged from $316 \mathrm{lb} /$ day fished during 2002 to $1,175 \mathrm{lb} /$ day fished in 2008 (Fig. 4), with CPUE increasing over this time series despite a trend of de-

creasing fishing effort $(\mathrm{F}=32.7, \mathrm{df}=1,26$, $\mathrm{P}<0.001, \mathrm{R}^{2}=0.56$ ).

\section{Discussion}

The goal of this work was to describe the GOM commercial white shrimp catch statistics. The collection of these commercial fishing statistics was initiated in the mid 1950's, about the time period when brown and pink

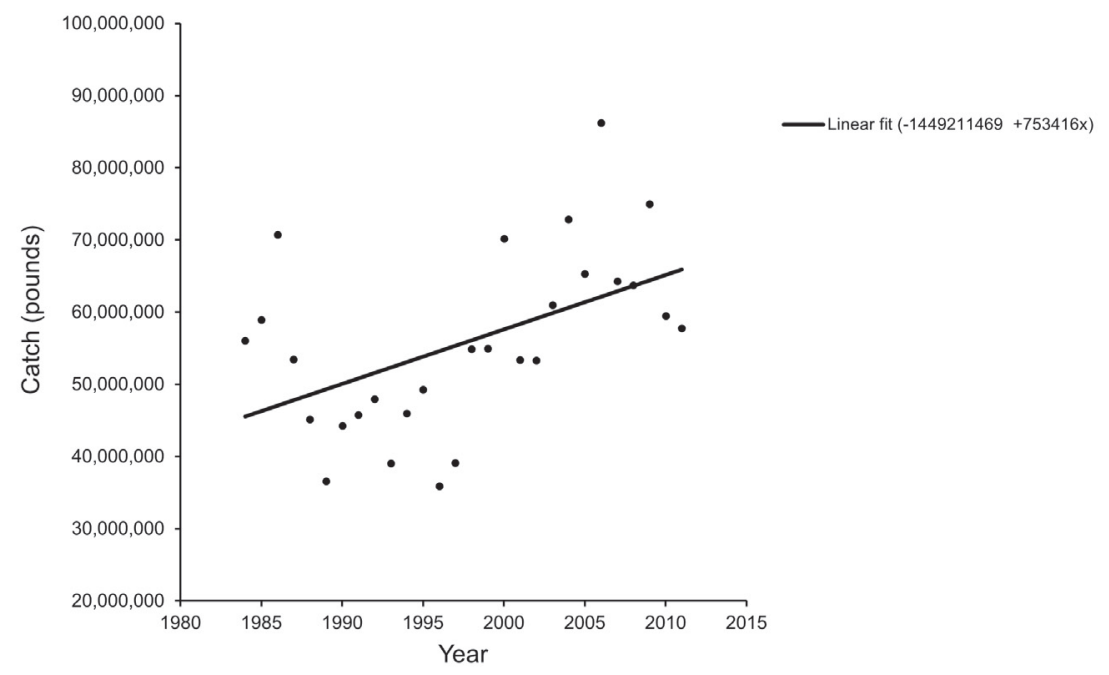

Figure 3.-Litopenaeus setiferus landings vs. year, 1984-2011. 


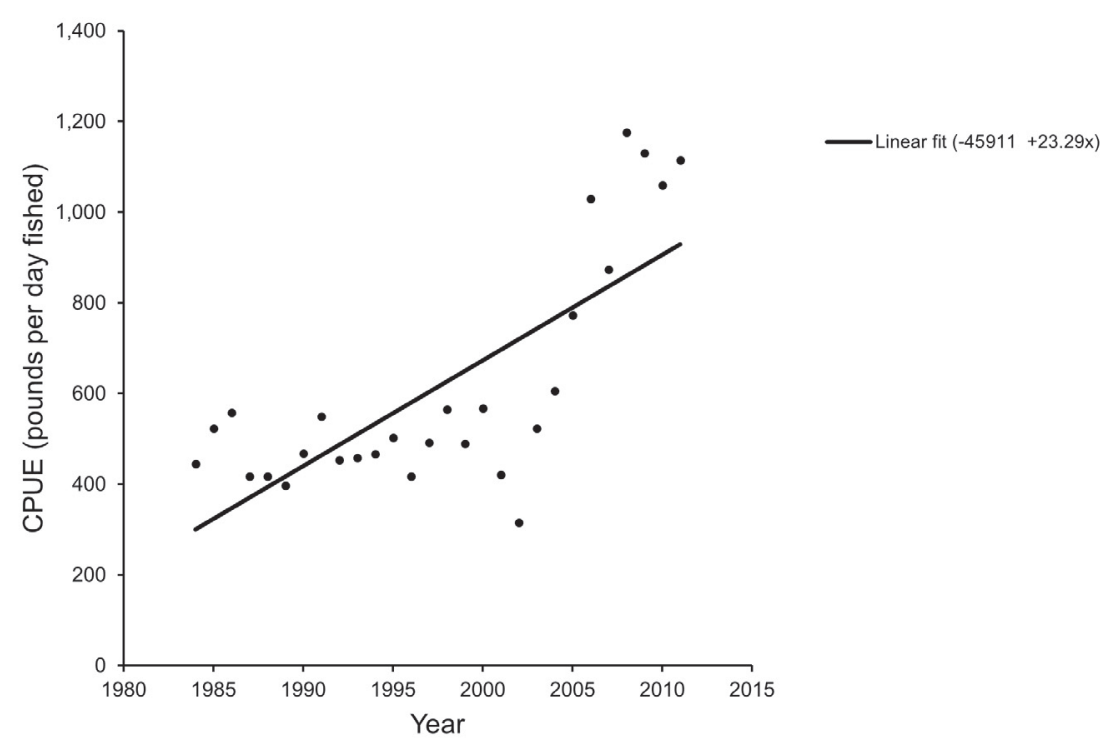

Figure 4.-Litopenaeus setiferus catch rate (CPUE) vs. year, 1984-2011.

shrimp overtook white shrimp in terms of total annual landings (Kutkuhn, 1962). These statistics have been used since that time to elucidate trends and changes in the fishery (Kutkuhn, 1962; Neal, 1975; Rothschild and Brunemeister, 1984; Neal and Maris, 1985; Nance et al., 2010; Hart, 2012). Catch and effort data are often used to develop CPUE trends which not only illustrate the fishing efficiency of the fleet, but also show the availability of the shrimp to harvest.

The CPUE of $L$. setiferus has long been used as an index of fishable biomass (Kutkuhn, 1962). While exploring the possible reasons for declines in white shrimp landings in 1957, Kutkuhn (1962) noted that, while landings declined abruptly in that year, the CPUE-based fishable biomass index did not parallel this drop in landings. In the time series we analyzed we are seeing an overall trend in declining effort and increases in catch and CPUE.

Effort is integral to CPUE, and the effort decrease we measured shows that effort in 2011 has been reduced by over $50 \%$ when compared to the highest levels recorded in the early years of the data set, e.g., 1998-2004. These declining effort levels are most likely due to adverse economic condi- tions that the fishing community has been experiencing during this time period (Travis and Griffin ${ }^{2}$ ).

While identifying and describing all of the factors contributing to the increase in effort from 1998-2004 and the dramatic decline in fishing effort after that time period is outside the scope of this paper, possible reasons for declining effort include: the devastation caused by hurricanes Katrina and Rita (2005) and Gustav and Ike (2008); an increase in competition with foreign shrimp products which has resulted in a decline in the price received by the fishermen (Keithly and Roberts, 2000; Haby et al., 2003); and an increase in marine fuel prices (Haby et al., 2003).

In the GOM white shrimp fishery, directed effort began to decline in earnest in 2005, interestingly coinciding with those major hurricanes which all made landfall on the Gulf Coast white shrimp fleet port areas. In addition, the recent Deep Water Horizon (DWH) oil spill in the Gulf of Mexico on 20 April 2010, resulted in approximately

${ }^{2}$ Travis, M. D., and W. L. Griffin. 2004. Update on the economic status of the Gulf of Mexico commercial shrimp fishery. SERO-ECON-04-01 Rep., 10 p. Avail. online at http://sero.nmfs. noaa.gov/sf/socialsci/pdfs/EconUpdateGulfShrFinal.pdf.
$40 \%$ of the U.S. Exclusive Economic Zone (EEZ) in the GOM having to be temporarily closed to commercial and recreational fishing $\left(\mathrm{NOAA}^{3}\right)$. All of these factors have resulted in the number of federally permitted shrimp fishing vessels to steadily decline (NMFS unpublished data, personal observ.) since a fishing permit moratorium was put in place in 2006.

Concurrently with decreasing fishing effort, catch has increased significantly over the time series. Recently, catch is slightly greater than the longterm average. The disproportional changes in catch and effort have led to large increases in catch rates. The catch rate during the last year (2011) of our data set is about three times greater than the 1984 rate. Nance et al. (2010) found similar trends of increasing CPUE and declining effort in their analytical analysis of the white shrimp data set. Furthermore, our time series has five more recent years of data, revealing that the increasing CPUE and decreasing effort trends elucidated by Nance et al. (2010) have continued through 2011.

These record high catch rates we have recently measured are an indication that the L. setiferus population has remained large enough not to be negatively affected by current high levels of catch. This finding also is evident in the most recent GOM L. setiferus stock assessment modeling results (Hart, 2012) and is another indication that the fishery during this time period is not in a measurable decline.

The availability of decades of catch and effort data have led to the development of robust stock assessment models which have successfully measured the performance and "health" of the fishery in the past (Nance et al., 2008; Hart, 2012). The newest model has been successful in its ability to track these extreme changes in catch, effort, and catch rates (Hart, 2012). Therefore it is possible that long-term impacts

${ }^{3}$ National Oceanic and Atmospheric Administration (NOAA). 2011. Deepwater Horizon/BP Oil Spill: 100 Days - a snapshot of NOAA's response. Avail. online at http://archive.orr.noaa. gov/dwh.php?entry_id=809. Accessed 4 April 2013. 
of human-caused and natural disasters noted previously will be elucidated with the use of the new stock assessment model using the data presented herein. Having this long-term baseline data puts the NMFS in a unique position to better measure future biological and economic impacts on this fishery.

\section{Acknowledgments}

We thank Jo Anne Williams (NMFS SEFSC) for drafting the chart and for assistance with figures; and James Primrose (NMFS SEFSC) and John Cole (LGL Ecological Research Associates, Inc.) for developing data summaries used in our analysis. The editor and two anonymous reviewers provided valuable comments on an earlier version of this manuscript.

\section{Literature Cited}

Burkenroad, M. D. 1934. The Penaeidae of Louisiana with a discussion of their world relationships. Bull. Am. Mus. Nat. Hist. 68(2):61-143.

1939. Further observations on Penaeidae of the northern Gulf of Mexico. Bull. Bingham Oceanogr. Coll. 6(6):1-62.

Baker, R., and T. J. Minello. 2010. Growth and mortality of juvenile white shrimp, Litopenaeus setiferus, in a marsh pond. Mar. Ecol. Progr. Ser. 413:95-104.

Condrey, R., and D. Fuller. 1992. The US Gulf shrimp fishery. In M. H. Giantz (Editor), Climate variability, climate change and fisheries, p. 89-119. Cambr. Univ. Press, U.K.

Gallaway, B. J., J. G. Cole, L. M. Martin, J. M.
Nance, and M. Longnecker. 2003a. An evaluation of an electronic logbook as a more accurate method of estimating spatial patterns of trawling effort and bycatch in the Gulf of Mexico shrimp fishery. N. Am. J. Fish. Manage. 23:787-809.

2003b. Description of a simple electronic logbook designed to measure effort in the Gulf of Mexico shrimp fishery. N. Am. J. Fish. Manage. 23:581-589.

Haby, M. G., R. J. Miget, L. L Falconer, and G. L Graham. 2003. A review of current conditions in the Texas shrimp industry, an examination of contributing factors, and suggestions for remaining competitive in the global shrimp market. Tex. A\&M Univ. Sea Grant Coll. Rep. TAMU-SG-03-701, 26 p.

Hart, R. A. 2012. Stock assessment of white shrimp (Litopenaeus setiferus) in the U.S. Gulf of Mexico for 2011. U.S. Dep. Commer., NOAA Tech. Memo. NMFS-SEFSC-637, 36 p.

J. A. Primrose, and J. M. Nance. 2012. The U.S. Gulf of Mexico pink shrimp, Farfantepenaeus duorarum, fishery: 50 years of commercial catch statistics. Mar. Fish. Rev. 74(1):1-6.

Keithly, W. R., and K. J. Roberts. 2000. Economics: contrast with wild catch fisheries. In R. R. Stickney (Editor), Encyclopedia of aquaculture, p. 261-277. John Wiley \& Sons, Inc., N.Y.

Klima, E. F., K. N. Baxter, and F. J. Patella, Jr. 1982. A review of the offshore shrimp fishery and the 1981 Texas closure. Mar. Fish. Rev. 44(9-10):16-30.

Kutkuhn, J. H. 1962. Gulf of Mexico commercial shrimp populations-trends and characteristics, 1956-59. Fish. Bull. 62:343-402.

Linder, M. J., and W. W. Anderson. 1956. Growth, migrations, spawning and size distribution of shrimp Penaeus setiferus. Fish. Bull. 56(106):553-645.

Nance, J. M., C. W. Caillouet, Jr., and R. A. Hart. 2010. Size-composition of annual land- ings in the white shrimp, Litopenaeus setiferus, fishery of the northern Gulf of Mexico, 1960-2006: its trends and relationships with other fishery-dependent variable. Mar. Fish. Rev. 72(2):1-13.

W. Keithly Jr, C. Caillouet Jr, J. Cole, W. Gaidry, B. Gallaway, W. Griffin, R. Hart, and M. Travis. 2008. Estimation of effort, maximum sustainable yield, and maximum economic yield in the shrimp fishery of the Gulf of Mexico. U.S. Dep. Commer., NOAA Tech. Memo. NMFS-SEFSC-570, 71 p.

, E. F. Klima, and T. E. Czapla. 1989. Gulf of Mexico shrimp stock assessmen workshop. U.S. Dep. Commer., NOAA Tech. Memo. NMFS-SEFSC-239, $41 \mathrm{p}$

Neal, R. A. 1975. The Gulf of Mexico research and fishery on penaeid prawns. In P. C. Young (Editor), First Australian national prawn seminar, Macroochydore, Queensland, Northern Fisheries Research Committee, p. 2-8. Australian Gov. Publ. Serv., Canberra. and R. C. Maris. 1985. Fisheries biology of shrimps and shrimplike animals. In A. J. Provenzano, Jr. (Editor), Economic aspects: fisheries and culture, vol. 10. The biology of crustacea, p. 1-110. Acad. Press, Inc. N.Y.

Patella, F. 1975. Water surface area within statistical subareas used in reporting Gulf coast shrimp data. Mar. Fish. Rev. 37(12):22-24.

Rothschild, B. J., and S. L. Brunenmeister. 1984 The dynamics and management of shrimp in the northern Gulf of Mexico. In J. A. Gulland and B. J. Rothschild (Editors), Penaeid shrimps - their biology and management, p.145-172. Fishing News Books Ltd., Farnham, Surrey, U.K.

Rozas, L. P., and T. J. Minello. 2011. Variation in penaeid shrimp growth rates along an estuarine salinity gradient: implications for managing river diversions. J. Exp. Mar. Biol. Ecol. 397(2):196-207.

Zar, J. H. 1984. Biostatistical analysis. 2nd ed. Prentice-Hall, Englewood Cliffs, N.J., 718 p. 